J.D. Gowan MBECH FFARCSI, J.B. Hurtig MD FRCPC, R.A. Fraser RN BSC, E. Torbicki MD FRCPC, J. Kitts MD FRCPC

\title{
Naloxone infusion after prophylactic epidural morphine: effects on incidence of postoperative side- effects and quality of analgesia
}

There have been conflicting repurts of the value of maloxone infusions to prevent the side-effects associated with epidural morphine. In our study, 29 patients undergoing thoracotomies for pulmonary surgery received epidural morphine $\left(0.1 \mathrm{mg} \cdot \mathrm{kg}^{-1}\right)$ shortly after induction of anaesthesia. One hour after arrival in the Recovery Room, one of four naloxone bolus and infusion sequences was administered: saline bolus followed by saline infusion; $0.4 \mu \mathrm{g} \cdot \mathrm{kg}^{-1}$ naloxone balus followed by $0.4 \mu \mathrm{\mu g} \cdot \mathrm{kg}^{-1} \cdot \mathrm{hr}^{-1}$ naloxone infusion; $2.0 \mu \mathrm{g} \cdot \mathrm{kg}^{-1}$ naloxone bolus followed by 2.0 $\mu \mathrm{g} \cdot \mathrm{kg}^{-1} \cdot \mathrm{hr}^{-1}$ naloxone infusion; and $4.0 \mu \mathrm{g} \cdot \mathrm{kg}^{-1}$ naloxone bolus followed by $4.0 \mu \mathrm{g}^{\circ} \mathrm{kg}^{-1} \cdot \mathrm{hr}^{-1}$ naloxane infusion

Although with the number of patients sfudied, there were no statistically significant differences among groups, clinically, there was a trend toward decreased analgesia with ail three naloxone infusian doses as determined by analgesic requirements, longest analgesic-free period and vistal anaiogue pain scores. In addition, side-effects occurred in all groups. We conclude that prophylactic naloxone, used in this manner, is not an appropriate iechnique for the prevention of side-effects associated with epidural morphine used for the prevention of pain after thoracotomy.

\section{Key words}

ANTAGONISTS, NARCOIJ: naloKOnE; ANAESTHETIC TECHNIQUE: epidural; ANALGESICS, NARCOTIC: morphine, epidural; ANAESTHESIA: recovety, postoperative analgesia.

From The Department of Anaesthesia, Ottawa Civic Hospital, and The University of Ottawa, Ottawa, Ontario.

Address correspondence to: Dr. J.B. Hurtig, Department of Anaesthesia C3, Ottawa Civic Hospital, 1053 Carling Ave., Ottawa, Ontario K1Y 4E9.
The use of epidural morphine is a well established technique for the treatment and prophylaxis of postoperative pain. ${ }^{1,2}$ In spite of earlier studies ${ }^{3}$ stressing the segmental distribution of analgesia following epidural morphine, the lumbar administration of epidural morphine has been proven to be as effective as thoracic administration in providing postoperative analgesia after thoracotomies with respect to dosage, duration and quality of analgesia. ${ }^{4}$

Side effects of epidural morphine administration occur quite frequently, but are easily treated. These include nausea and yomiting (17 to 50 per cent incidence), ${ }^{3,6}$ pruritus ( 1 to 28 per cent), ${ }^{7,8}$ and urinary retention (4 to 39 per cent).$^{9.8}$ Clinically significant respiratory depression is unusual, occurring only 22 times in $6000-9150$ cases in one large series, ${ }^{10}$ and in 19 of 14,000 cases in a recent survey. " However, it is unpredictable in its timing and serious in its consequences.

Preliminary reports suggest that a naloxone infusion $\left(5 \mu \mathrm{g} \mathrm{kg}^{-1} \cdot \mathrm{hr}^{-1}\right)$ is effective in preventing the respiratory depression of epidural morphine, with no subsequent loss of analgesia ${ }^{12,13}$ Used as a single bolus, followed by a continuous infusion, naloxone has been shown to reduce the incidence of nausea, pruritus and urinary retention following intrathecal morphine in labour. ${ }^{13}$

To examine the effects of naloxone infusions in patients receiving prophylactic lumbar epidural morphine for post-thoracotomy analgesia, a double-blind, randomized, placebo-controlled study was initiated to determine the appropriate dose of naloxone to be used in the prevention of side effects associated with epidural morphine, and to examine the quality of analgesia obtained with each dose studied.

Methods

Twenty-nine patients scheduled for thoracotomy and 
lobectomy or pneumonectomy as a result of pulmonary neoplasm gave informed consent and were admitted to the study. The protocol was approved by our hospital Human Research Committee.

The study population consisted of 18 men and 11 women. The mean $( \pm S D)$ age was $61.1( \pm 8.9)$ years; mean weight $67.1( \pm 12.2) \mathrm{kg}$; mean height $168.8( \pm 10.3) \mathrm{cm}$. Patients with a history of biliary colic, obstructive uropathy, who were pregnant or who required more than four hours of postoperative mechanical ventilation during the study period were excluded. No subject look monoamine oxidase inhibitors, major tranquillizers, barbiturates, tricyclic antidepressants, anticoagulants or narcotics in the two weeks prior to the study. Also excluded were patients in whom the placement of an epidural catheter was contraindicated or with a demonstrated allergy to narcotics.

At the time of the screening interview, informed consent was obtained and all subjects were instructed in the completion of the visual analogue scale $e^{14}$ (VAS) for pain intensity. A preoperative VAS was obtained indicating the points that subjects considered best fitted the verbal pain descriplors "mild, moderate and severe." These verbal descriptors were used postoperatively when the patient was unable to mark a visual andog scale card.

Baseline arterial blood gases, forced expiratory volume in one second $\left(\mathrm{FEV}_{1}\right)$ and forced vital capacity (FVC), were obtained preoperatively.

Patients were premedicated with oral diazepam one to two hours prior to surgery to a maximum dose of 0.2 $\mathrm{mg} \cdot \mathrm{kg}^{-1}$. At the time of surgery, an epidural catheter was inserted at the $\mathrm{L}_{2-3}$, or $\mathrm{L}_{3-4}$ level, and placement confirmed with a test dose of 3-5 ml of cartonated two per cent lidocaine without epinephrine. Anaesthesia was then induced following defasciculation with d-tubocurarine or pancuronium, with thiopentone $2-5 \mathrm{mg} \cdot \mathrm{kg}^{-1}$ and succinylcholine $1.5-2.0 \mathrm{mg} \cdot \mathrm{kg}^{-1}$ (or a non-depolarizing agent) to facilitate intubation.

Preservative-free morphine sulphate, $0.1 \mathrm{mg} \cdot \mathrm{kg}^{-1}$, was administered through the epidural catheter with the patient supine and the patient was maintained in this position for 15 minutes prior to positioning for surgery.

Anaesthesia was with $\mathrm{O}_{2}$ and $\mathrm{N}_{2} \mathrm{O}$ with isoflurane in appropriate concentrations to maintain surgical anaesthesia. Fentanyl $2-5 \mu \mathrm{g} \cdot \mathrm{kg}^{-1}$ was added intravenously as required, and muscle relaxation was with the nondepolarizing agent of the individual anaesthetist's choice. At the end of surgery, muscle relaxation was reversed with an anti-cholinesterase and atropine.

On anrival in the Recovery Room (RR), it was noted whether or not the patient was being mechanically ventilated, and if so, the time to discontinuation and extubation was recorded. Prior to the start of the study
TABLE I Medication groups: $n=29$

\begin{tabular}{llll}
\hline Croup & n & Single IV Bolus & $\begin{array}{l}\text { Continuous infusion } \\
\text { for 20 hours }\end{array}$ \\
\hline I & 8 & $0.9 \% \mathrm{NaCl}$ & $0.9 \% \mathrm{NaCl}$ \\
II & 8 & naloxone $0.4 \mu \mathrm{g} \cdot \mathrm{kg}^{-1}$ & naloxone $0.4 \mu \mathrm{g} \cdot \mathrm{kg}^{-1}$ \\
III & 8 & naloxone $2.0 \mu \mathrm{g} \cdot \mathrm{kg}^{-1}$ & naloxone $2.0 \mu \mathrm{g} \cdot \mathrm{kg}^{-1}$ \\
IV & 5 & naloxone $4.0 \mu \mathrm{g} \cdot \mathrm{kg}^{-1}$ & naloxone $4.0 \mu \mathrm{g} \cdot \mathrm{kg}^{-1}$ \\
\hline
\end{tabular}

medication, a baseline pain assessment (VAS) was obtuined and the following vital signs were recorded: hear sate, blood pressure, respiratory rate, pupil size (mm). In addition, end-tidal $\mathrm{CO}_{2}$ (Datex $\mathrm{CO}_{2}$ Monitor, PuritanBennett Corp.) was measured with an indwelling nasopharyngeal catheter.

According to the assigned patient number and randomization schedule (Table I), one hour after arrival in the $R R$, each patient received a single intravenous bolus of placebo/naloxone study medication. Within 30 minutes, this was followed by a continuous infusion of the same hourly dose of study medication over the succeeding 20 hours.

In each case, the intravenous bolus volume was kept constant at $0.1 \mathrm{mg} \cdot \mathrm{kg}^{-1}$, and the continuous infusion flow rate at $0.5 \mathrm{mg} \cdot \mathrm{kg}^{-1} \cdot \mathrm{hr}^{-1}$ (Life Care Pump, Abbott Laboratories). Neither the patient nor the investigators were aware of which medication regime was being used.

Patients were nursed in the semi-sitting position in the RR for 24 hours afte the epidural morphine injection. Pain assessment and vital signs were repeated at 15,30 and 45 minutes, then hourly for 20 hours after the administration of the study medication. The following were treated as efficacy variables during administration of naloxone: (1) the total amount of morphine given, (2) the longest interval between analgesic administrations, and (3) the VAS.

Treatment of pain postoperatively was with intravenous morphine in $1 \mathrm{mg}$ increments given as reguired. Treatment failure was acknowledged if the pain could not be controlled with the safe administration of a maximum of $15 \mathrm{mg}$ of intravenous morphine in 20 minutes.

The presence of any side-effects attributable to the technique, specifically nausea and vomiting, pruritus, urinary retention and respiratory depression, was recorded. Urinary retention was defined as either the patient's complaint of inability to void, or a distended bladder requiring catheterization. Respiratory depression was defined as: (1) $\mathrm{PaCO}_{2}$ greater than $55 \mathrm{mmHg}$, (2) a respiratory rate less than $9 \cdot \mathrm{min}^{-1}$ or (3) apnoeic spells lasting more than ten seconds. All side-effects were treated as appropriate. All drug administrations to patients during the study period were recorded.

The data were analysed using one-way analysis of 
TABLE II Times and measons for study drug discontinuations

\begin{tabular}{|c|c|c|c|}
\hline Patient & Group & $\begin{array}{l}\text { Time infusion } \\
\text { discontinued* }\end{array}$ & Reason \\
\hline $0 \mathbf{I}$ & IV & 11 hours & Immediate increase in pain when study bolus given \\
\hline 07 & II & 161 hours & Suldy D/C due to onset of supraventricular tachycardia \\
\hline 12 & IV & 31 hours & $\begin{array}{l}\text { Moderate/severe pain since arival in RR. Unable to give } \\
\text { adequate control with IV analgesia }\end{array}$ \\
\hline 15 & II & 18 hours & Poor pain relief \\
\hline 20 & IV & $12 \frac{1}{3}$ hours & $\begin{array}{l}\text { co modcrate pain immediately post study bolus, } \\
\text { required excessive IV analgesia and study DiC due to } \\
\text { onset of chest pain }\end{array}$ \\
\hline 32 & III & $4 \frac{1}{2}$ hours & $\begin{array}{l}\text { Pain since arrival in } \mathrm{RR} \text {. Infusion discontinued at } \\
\text { patient's request }\end{array}$ \\
\hline
\end{tabular}

*Refers to time interval since commencing study dng bolus'infusion.

variance (ANOVA). VAS scores were analysed using two way ANOVA with repeated measures. Dunnett's test for intra-group comparisons was performed on the VAS data. For all statistical analysis a degree of probability $p \leq 0.05$ was used to indicate significunce.

\section{Results}

There were no significant differences in the demographic data among the four groups (one way ANOVA). Doses of intraoperative fentanyl were similar among groups. No patients required prolonged ventilatory assistance after surgery.

Two-thirds of the way through the study, as a result of clinical evidence of significant reversal of analgesia in some patients after starting the study drug, the randomization code for the high-dose group $\left(4.0 \mu \mathrm{g} \cdot \mathrm{kg}^{-1} \cdot \mathrm{hr}^{-1}\right)$ was broken by our pharmacy department. They confirmed that the five patients that had been in the high dose group thus far had either had their infusions discontinued due to inadequate pain relief or had required above average doses of analgesia. This group was removed from further study, and the remaining patients in the high-dose group were rerandomized into Groups I-III. The naloxone/placebo study medication infusion was discontinued in a total of six patients, and the reasons for discontinuance are noted in Table II. As we were studying the effects of naloxone administration, only data prior to study drug termination. were included in analysis.

During the first hour in the RR before commencing the naloxone infusion, there were no significant differences among the groups with respect to: (a) the amount of intravenous morphine required, (b) the longest interval between analgesics or (c) the mean VAS (one way ANOVA). There were insufficient data in Group IV after the first hour after commencement of naloxone (due to discontinuations of treatment) to warrant analysis.

In the 20-hour study period following the commencement of analoxone there was no statistically significant difference among groups with respect to (a) the amount of intravenous marphine required, (b) the longest interval between analgesics, or (c) the VAS scores (two-way ANOVA) (Table III and Figure). The efficacy variables including the mean VAS scores in the first four 15-minute pcriods (first hour) after commencement of naloxone, were re-examined to include all four groups. No significant differences among groups were found (Table III).

TABLE 11 Efficacy variables after commencing naloxone infusion

\begin{tabular}{llllll}
\hline Group & $N$ & V morphine & $\begin{array}{l}\text { Longest interval } \\
\text { between analge.jics }\end{array}$ & VAS $(20 \mathrm{~h})^{*}$ & VAS $($ lst h) \\
\hline I & 8 & $23.6 \mathrm{mg}$ & $436.4 \mathrm{~min}$ & $26.1 \pm 2.8$ & $37.0 \pm 7.0$ \\
II & 8 & $23.4 \mathrm{mg}$ & $375.6 \mathrm{~min}$ & $31.2 \pm 7.6$ & $35.7 \pm 13.5$ \\
III & 8 & $27.0 \mathrm{mg}$ & $247.9 \mathrm{~min}$ & $34.4 \pm 5.7$ & $49.8 \pm 11.3$ \\
IV & 5 & $30.4 \mathrm{mg}$ & $115.0 \mathrm{~min}$ & & $62.3 \pm 10.3$ \\
p & & NS & NS & NS & NS \\
\hline
\end{tabular}

"VAS scores are the values obtained when the mean scores for each group, for each time interval, are themselves accumulated and an overall mean VAS score \pm one standard error of the mcan, obtained for each group.

†VAS scores in this column refer to overall mean scores obtained in the four time intervals, in the first hour, after commencing the naloxone infusion.

NS: Not statistically significant. 
Figure Hourly Group Mean V.A.S. Scores

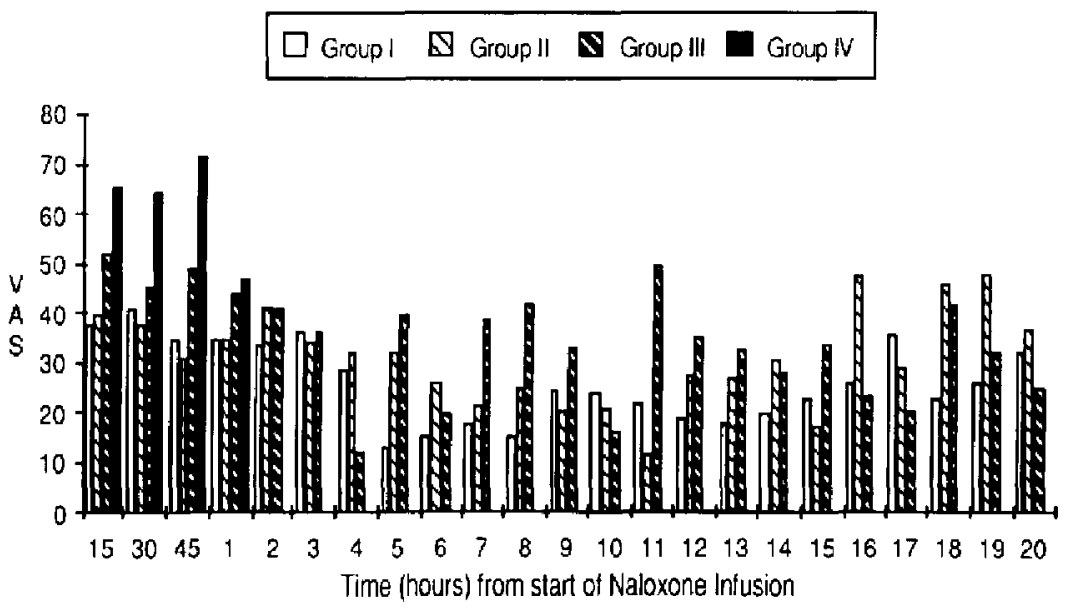

FIGURE Hourly group mean VAS scores. Using ANOVA, no significant differences were found between groups in either the first hour or the first 20 postoperative hours $(p=0.55)$. As expected, significant diffcrences in VAS scores were found within groups over time $(p<0.05)$.

However, when the trends in the VAS scores are examined, it is evident that a worsening in pain scores did occur with inceasing concentration of naloxone infusion. These trends were evident both in the scores for the first hour after commencment of naloxone, and in the scores for Groups I-III over 20 hours (Figure). In the first hour, no significant difference was found either among or within groups. A significant difference was found in VAS scores within groups across time indicating a high degree of variability in each patient's scores when recorded at each time interval.

The frequency of nausea and vomiting, pruritus, urinary retention and respiratory depression, is shown in Table IV. Side effects occurred in all four groups. Only the patients in Group II (naloxone $0.4 \mu \mathrm{g} \cdot \mathrm{kg}^{-1} \cdot \mathrm{hr}^{-1}$ ) complained of pruritus ( 50 per cent). Six patients developed respiratory depression, three of whom were in the saline control group. There were insufficient numbers in each group to statistically analyse the results.

\section{Discussion}

Two recent studies ${ }^{12,13}$ suggested naloxone infusions might be useful in the prevention of side-effects associated with epidural norphine without affecting analgesia. Rawal and Schott ${ }^{12}$ employed thoracic epidurals for postoperative analgesia in patients scheduled for gallbladder surgery. Unlike our own study, they administered epidural morphine postoperatively at the patient's first
TABLE IV Frequency of side-effects in each group

\begin{tabular}{lllll}
\hline & $\begin{array}{l}\text { Nausea and } \\
\text { womiting }\end{array}$ & Pruritus & $\begin{array}{l}\text { Urinary } \\
\text { retention }\end{array}$ & $\begin{array}{l}\text { Respiratory } \\
\text { depression }\end{array}$ \\
\hline Group I & 4 & 0 & 7 & 3 \\
Group II & 3 & 4 & 7 & 1 \\
Group III & 4 & 0 & 6 & 2 \\
Group IV & 1 & 0 & 3 & 0 \\
\hline
\end{tabular}

request for additional analgesia in a fixed dose of $4 \mathrm{mg}$. In addition, they adminiștered $8-10 \mathrm{ml}$ or two per cent mepivacaine perioperatively and higher infusion concentrations of naloxone ( 5 and $10 \mu \mathrm{g} \cdot \mathrm{kg}^{-1} \cdot \mathrm{hr}^{-1}$ ), All the patients in this study rated their analgesia as "good or excellent," although patients receiving the larger dose of naloxone had decreased durations of analgesia. Respiratory depression did not occur in either naloxone group. Criteria for respiratory depression were not defined

Thind ${ }^{13}$ studied 45 women, who had received 18-26 $\mathrm{ml}$ of 0.5 per cent bupivacaine with epinephrine for Caesarian section, and divided them into three groups. The first group $(n=15)$, received in addition, $4 \mathrm{mg}$ of epidural morphine upon delivery and, one hour later, a bolus/infusion sequence of intravenous naloxone. The concentration of the infusion was $1.4 \mathrm{mg}$ naloxone in one litre of lactated Ringer's solution. Consequently, they too, used a lower dose of epidural morphine and higher naloxone infusion concentrations. None of their patients 
reported maximum VAS pain scores greater than $40 \mathrm{~mm}$ in the first 24 hours after delivery. In both these studies, the presence of epidural local anaesthetic may well have been a significant factor in improving the postoperative pain scores.

There has been much controversy in the past over whether one shoud use parametric or non-parametric analysis for pain scale data. The use of a verbal rating scale which is classified as an ordinal scale leads to a non-parametric analysis while parametric analysis is most appropriate for those scales classified as interval or ratio scales. The visual analogue scale has often been considered to yield scores at least at an interval scale level ${ }^{15,16}$ and Price et al. ${ }^{17}$ have validated the VAS as a ratio scale measure for experimental and chronic pain. The fact that it has been validated as a ratio scale in clinical pain, the differences between acute and chronic pain notwithstanding, led us to utilize parametric tests.

It was our impression that analgesia in our patients was detrimentally affected by prophylactic naloxone infusions in the dose ranges studied. Despite the blinded nature of the study, attending nursing staff in the RR reported, in many cases, an increase in pain, immediately or soon after giving the bolus of study medication and commencing the study. Because of the small numbers in each group, statistical analysis failed to show significant differences in pain scores among the groups. Nevertheless, when the mean VAS values for each group at each time interval are compared, a definite trend may be observed, with the control group generally having the lowest scores (Figure). This is particularly evident in the first 12 hours after commencing the naloxone infusions. Since we concluded that the use of naloxone in this fashion was a poor treatment approach, we did not feel justified in continuing the study so as to have an adequate population to achieve statistical significance.

Ramanthan et al. ${ }^{18}$ compared patients having prophylactic epidural morphine for post-Caesarian section analgesia with a similar group treated in addition with prophylactic naloxone infusions $\left(100 \mu \mathrm{g} \cdot \mathrm{hr}^{-1}\right)$ and found significantly higher pain scores (VAS) in the naloxone group. Neither the incidence nor the severity of pruritus, commonly seen after epidural morphine in pregnant patients, was affected by the infusions. The number of patients complaining of nausea was 33 per cent in the epidural morphine group compared to 55 per cent in the group receiving epidural morphine and the prophylactic naloxone infusion. In our study, although the numbers are small, there was no trend towards prevention of side effects with increasing dose of naloxone. Indeed the presence of thesc side-effects, particularly respiratory depression after thoracotomy, might have been related to factors other than the epidural morphine.
The necessity of discontinuing the naloxone in six patients and removing them from the study at that point has implications for the observed results. This factor may have minimized the cumulative observed trends towards increased analgesic requirements, and worsening VAS pain assessments with increasing dose of naloxone.

The fact that we did not include epidural local anacsthetic in our regimen sets our naloxone study apart from those discussed above. Other differences include lumbat administration of morphine for thoracic surgery, and an elderly patient population. Animal studies in rats and dogs suggest that, at lower doses, naloxone binding occurs only at high affinity mu receptors (those mediating respiratory depression), while at higher doses, binding occurs in addition at kappa receptors which mediate spinal analgesia. ${ }^{19.20} \mathrm{It}$ is possible that in our thoracotomy patients with a mean age of 61.1 years, the dose range for both the naloxone bolus $\left(0.4-4.0 \mu \mathrm{g} \cdot \mathrm{kg}^{-1}\right)$ and infusion $0.4-4.0 \mu \mathrm{g} \cdot \mathrm{kg}^{-1} \cdot \mathrm{hr}^{-1}$ ) could constitute a sufficiently high dose to interact with both mu and kappa opioid receptor subtypes. Alternatively, with lumbar administration of epidural morphine, the morphine concentration in the thoracic region may have been inadequate to tolerate a narcotic antagonistic effect at that site.

It also might be expected that with time the analgesic effect of the epidural morphine would regress, and a constant infusion of naloxone would become increasingly antagonistic. There are no clinical pharmacodynamic data in the literature relating to lumbar epidural morphine for the prevention of thoracotomy pain, and the present study did not address this issue.

It is therefore our impression that this technique of prophylactic naloxone infusion, in the described dose range, is less than satisfactory in maintaining postthoracotomy analgesia and in preventing side-effects associated with intraoperatively administered epidural morphine.

\section{Acknowledgments}

We would like to thank Dr. H. Sachs and Dr. F. Shamji of the Division of Thoracic Surgery for their cooperation during this study and Dr. K. Dulberg of the Department of Epidemiology and Community Medicine, University of Ottawa for statistical consultation and analysis. The research was supported by an operating grant from A.H. Robins Company and equipment grants from the PuritanBennett Corp. and Abbott Laboratories Ltd. We would also like to thank Du Pont Canada Inc. for supplying the naloxone. 


\section{References}

1 Cousins $M J$. Mather $L E$. Intrathecal and epidural administration of opinids. Anesthesiology 1984; 61: 276-310.

2 Writer WDR, Hurtig JB, Evans $D$ et al. Epidural morphine prophylaxis of postoperative pain: report of a double-blind multicentre study. Can Anaesth Soc J 1985; 32: 330-8.

3 Asari $H$, Inoue $K$, Shibata $T$, Soga $T$. Segmental effect of morphine injected into the epidural space in man. Anesthesiology 1981; 54: 75-7.

4 Fromme GA, Steidl LI, Danielson DR. Comparison of lumbar and thoracic epidural morphine for relief of postthoracotomy pain. Anesth Analg 1985; 64: 454-5.

5 Reiz $S$, Westberg $M$. Side effects of epidural morphine. Lancet 1980; 2: 203-4.

6 Bromage PR, Camporesi EM, Durant PAC, Nielsen CH. Nonrespirutory side effects of epidural morphine. Anesth Analg 1982; 61: 490-5.

7 Bromage PR, Camporesi E, Chestnut D. Epidural narcotics for postoperative analgesia. Anesth Analg 1980; 59: 473-80.

8 Lanz E. Theiss D, Riess W. Sommer U. Epidural morphine for postoperative analgesia: $A$ double-blind study. Anesth Analg 1982; 6I: 236-40.

9 Torda TA, Pybus DA. Clinical experience with epidurat morphine. Anacsth Intensive Carc 1981; 9: 129-34.

10 Gustafsson LL, Schild: B, Jacobsen KJ. Adverse effects of extradural and intrathecal opiates: Report of a nationwide survey in Sweden. Br J Anaesth 1982; 54: 479-86.

11 RawalN, Arner $S$, Gustajsson LL, Allvin R. Present state of extradural and intrathecal opioid analgesia in Sweden. Br J Anaesth 1987; 59: 791-9.

12 Rawal N, Schött U, Dahlström B, et al. Influence of naloxone infusion on analgesia and respiratory depression following epidural morphine. Anesthesiology 1986; 64: 194-201.

13 Thind GS, Wells JCD, Wilkes RG. The effects of continuous intravenous naloxone on epidural morphine analgesia. Anaesthesia 1986, 41: 582-5.

14 Huskisson EC. Visual analogue scales. In: Pain measurement and assessment. R. Melzack (Ed). Raven Press, New York 1983: 33-7.

15 Carisson AM. Assessment of chronic pain. 1. Aspects of the reliability and validity of the visual analog scale. Pain 1983; 16: 87-101.

16 Price $D D$, Harkins SW, Baker C. Sensory affective relationships among different types of clinical and experimental pain. Pain 1987; 28: 297-307.

17 Price DD, McGrath PA, Rafii A, Buckingham $B$. The validations of visual analog scales as ratio scale measures for chronic and experimental pain. Pain 1983; 17 : $45-56$.
18. Ramanathan S, Uorn R. Parker F, Turndorf H. Naloxone infusion is ineffective in preventing the side-effects of epidural morphine in post-Cesarean section patients. Anesthesiology 1986; 65: A367.

19 Hensel $J$, Albrech $R F$, Miletich DI. The reversal of morphine mediated respiratory depression but not analgesia in rats. Anesthesiology 1983; 59: A195.

20 Gilbert PE, Martin WR. The effects of morphine and nalorphine-like drugs in the nondependent, morphinedependent and cyclazocine-dependent chronic spinal dog. J Pharmocal Exp Ther 1976; 198: 66-82.

\section{Résumé}

Une controverse persiste au sujet de l' utilité du naloxone dans la prévention des effets secondaires associés à la morphine en injection épidurale. Nous avons étudié 29 parients ayant subis une thoracotomie pour chirurgie pulmonaire et qui ont reçus 0.1 $\mathrm{mg} \cdot \mathrm{kg}^{-1}$ de morphine en injection épidurale petr apres l'induction de l'anesthèsie. Une heure après leur arrivée à la salle de réveil, on a administré une des quatres séquences suivantes d' un bolus de naloxone suivi d'une perfusion de naloxane: bolus de salin suivi d' une perfusion de salin; bolus $0.4 \mu \mathrm{g} \cdot \mathrm{kg}^{-1}$ de naloxone suivi d"une perfusion $0.4 \mu \cdot \mathrm{kg}^{-1} \cdot \mathrm{hr}^{-1}$ de moloxone; bolus 2.0 $\mu \mathrm{g} \cdot \mathrm{kg}^{-1}$ de naloxone suivi d' une perfusion $2.0 \mu \cdot \mathrm{kg}^{-1} \cdot \mathrm{hr}^{-1} \mathrm{de}$ naloxone; bolus $4.0 \mu \mathrm{\mu g}^{-1}$ de naloxone suivi d'une perfusion $4.0 \mu \cdot \mathrm{kg}^{-1} \cdot \mathrm{hr}^{-1}$ da maloxone. Dû au nombre restreint de patients étudiès, les résultats ne sont pas confirmés par analyse statistique. Mais de façon clinique, le degré d'analgésie a été diminué avec les trois doses de naloxane tel que déterminé par le besoin d'analgésique supplémentaire, l'espace de temps maximum entre les doses d'analgésie requises, et l'examen des analogues visuels de la douleur. L'incidence des effets secondaires n'a pas été modiftée. Nous concluons donc que les perfusions prophylatiques de naloxone, utilisées de cette façon, ne sont pas apropriées pour prévenir les effers secondaires de la morphine en injection épidurale pour soulager la douleur après une thoracotontie. 